\title{
EVALUASI SISTEM INFORMASI MANAJEMEN DAN AKUNTANSI BARANG MILIK NEGARA (SIMAK BMN) PADA KANTOR IMIGRASI KELAS II TAHUNA
}

\author{
Greise Majampoh $^{1}$, David P.E. Saerang ${ }^{2}$, I Gede Suwetja ${ }^{3}$ \\ ${ }^{1,2,3}$ Fakultas Ekonomi dan Bisnis. Jurusan Akuntansi. Universitas Sam Ratulangi, Jl. Kampus Bahu, Manado, \\ 95115, Indonesia
}

E-mail:greisemajampoh@gmail.com

\begin{abstract}
The State Property Management and Accounting Information System is a technology based apllication system implemented in the Class II Tahuna Immigration Office, with the aim of dealing with administration mainly covering state-owned assets. This study aimsto evaluate the performance of SIMAK BMN insupporting asset inventory at Tahuna Immigration Office. The research method is case study using descriptive research method. The data used are secondary data and primary data. With the technique of collecting interview data and documentation. The results of this study revealed that the work of SIMAK BMN can be viewed from the quality of information, Timeliness, ease of use SIMAK BMN and supporting and inhibiting factors. Of the four (4) points it is found that in the quality of information generated SIMAK BMN is very influential on the financial statements Immigration Office Tahuna, but there are still some factors that inhibit the work of SIMAK BMN from SIMAK $B M N$ and SIMAK BMN which is often wrong in the error.

Keywords: Management Information System and Accounting of State Property (SIMAK $B M N)$
\end{abstract}

\section{PENDAHULUAN}

Seiring dengan perkembangan teknologi yang semakin pesat diera sekarang sehingga berpengaruh pada banyak aspek, salah satunya adalah aspek ekonomi dan juga bisnis. Seperti halnya di berbagai bidang yang sedang berlangsung di Indonesia ini telah membawa perubahan terhadap sistem politik, sosial, kemasyarakatan serta ekonomi sehingga menimbulkan tuntutan yang beragam terhadap pengelolaan pemerintahan yang baik. Oleh karena itu pemerintah harus memiliki sistem informasi yang akurat, relevan, dan tepat waktu.

Undang-Undang Nomor 17 Tahun 2003 menyatakan bahwa semua hak dan kewajiban Negara yang dapat dinilai dengan uang, serta segala sesuatu baik berupa uang maupun berupa barang yang dapat dijadikan milik Negara berhubung dengan pelaksanaan hak dan kewajiban tersebut. Selain itu sebagai pelaksanaan dari ketentuan dari Pasal 48 ayat (2) dan Pasal 49 ayat (6) UU No.1 Tahun 2004 tentang Perbendaharaan Negara, dan untuk menjamin terlaksananya tertib administrasi dan tertib pengelolaan BMN/Daerah, maka pemerintah menerbitkan PP No.6 Tahun 2006 tentang Pengelolaan BMN/Daerah.

Sistem Akuntansi Pemerintah Pusat terdiri dari Sistem Akuntansi Pusat (SiAP) yang dilaksanakan oleh Direktorat Jenderal Perbendaharaan, dan Sistem Akuntansi Instansi (SAI) yang dilaksanakan oleh kementerian atau lembaga. Sistem Akuntansi Pusat (SiAP) terbagi dua subsistem yaitu Sistem Akuntansi Kas Umum Negara (SAKUN) dan Sistem Akuntansi Umum (SAU). Sedangkan Sistem Akuntansi Instansi (SAI) melakukan pemrosesan data untuk menghasilkan laporan keuangan berupa laporan realisasi anggaran, neraca dan catatan atas laporan keuangan. Dalam pelaksanaan Sistem Akuntansi Instansi (SAI), kementerian negara/lembaga membentuk dua unit Sistem Akuntansi Keuangan (SAK) dan Sistem Informasi Manajemen dan Akuntansi Barang Milik Negara (SIMAK BMN).

Sistem Informasi Manajemen Akuntansi Barang Milik Negara (SIMAK BMN) adalah sistem informasi yang memanfaatkan teknologi informasi dan komunikasi untuk 
memfasilitasi pengelolaan informasi administrasi kekayaan negara di setiap satuan kerja (satker) di kementerian dan lembaga pusat maupun instansi daerah (Rahmawati : 2014). SIMAK BMN sendiri merupakan penyempurnaan dari sistem/aplikasi yang sangat berkaitan dengan pengelolaan barang milik negara yang awalnya bernama SAAT (Sistem Akuntansi Aset Tetap), kemudian berubah menjadi aplikasi SABMN (Sistem Akuntansi Barang Milik Negara) dan akhirnya menjadi aplikasi SIMAK BMN (Sistem Informasi Manajemen dan Akuntansi Barang Milik Negara). Adapun lingkup dari BMN meliputi unsur - unsur aset lancer, aset tetap, aset lainnya dan aset bersejarah.

Barang Milik Negara tersebut sebagian besar diperoleh dari anggaran APBN yang notabene adalah uang rakyat sehingga pertanggung jawaban penatausahaan BMN harus sesuai dengan peraturan perundang - undangan yang mutlak diperlukan untuk meningkatkan akuntabilitas dan transparansi dalam pengelolaan keuangan Negara. Mengingat BMN sangat penting dalam berlangsungnya keuangan pemerintahan maka dalam penelitian ini bermaksud untuk mengetahui kinerja dari SIMAK BMN yang berlangsung di kantor Imigrasi Kelas II Tahuna, apakah dengan adanya SIMAK BMN perkejaan dapat dikerjakan tepat waktu atau masih terjadi kesalahan input dan output yang dihasilkan oleh SIMAK BMN. Berhubung dengan banyaknya jumlah Barang Milik Negara sehingga bisa terjadinya penyalahgunaan dan kesalahan dalam penatausahaan Barang Milik Negara pada aplikasi SIMAK BMN, dan bisa menimbulkan penyimpangan dalam penatausahaan Barang Milik Negara yang tidak sesuai dengan peraturan perundang - undangan. Maka dari itu untuk melihat kualitas dari SIMAK BMN juga dilihat dari segi operator SIMAK BMN, apakah telah menguasai dan memahami SIMAK BMN untuk itu operator tersebut harus memiliki pehaman yang baik dalam mengerjakan aplikasi SIMAK BMN, agar tidak terjadi kecurangan atau kesalahan dalam pengisian data Barang Milik Negara. Berdasarkan latar belakang penelitian, maka rumusan masalah pada penelitian ini adalah bagaimana Kinerja Sistem Informasi Manajemen dan Akuntansi Barang Milik Negara (SIMAK BMN) Pada Kantor Imigrasi Kelas II Tahuna ?, dimana tujuan yang ingin dicapai dalam penelitian ini adalah untuk mengetahui kinerja SIMAK BMN pada Kantor Imigrasi Kelas II di Tahuna.

\section{TINJAUAN PUSTAKA}

\subsection{Pengertian Akuntansi}

Akuntansi adalah seni pencatatan, penggolongan dan peringkasan transaksi dan melaporkan kejadian yang bersifat keuangan dengan cara yang berdaya guna dan dalam bentuk satuan uang dan menginterprestasikan hasil proses yang terjadi (Suwardjono, 2016:5).

\subsection{Akuntansi Sektor Publik}

\subsubsection{Pengertian Akuntansi sektor publik}

Akuntansi Sektor publik dapat didefinisikan sebagai aktivitas jasa yang terdiri dari mencatat, mengklasifikasikan, dan melaporkan kejadian atau transaksi ekonomi yang akhirnya akan menghasilkan suatu informasi keuangan yang akan dibutuhkan oleh pihak pihak tertentu untuk pengambilan keputusan, yang diterapkan pada pengelolaan dana publik di lembaga - lembaga tinggi Negara dan departemen - departemen dibawahnya (Sujarweni $2015: 1)$.

\subsubsection{Organisasi Sektor Publik}

Menurut (Sujarweni 2015 : 3) Organisasi sektor publik adalah organisasi yang berorientansi pada kepentingan publik, dan juga tidak berorientasi pada laba sebagai tujuan akhirnya. Jika dilihat secara garis besar, jenis - jenis organisasi sektor publik dapat dibagi menjadi 3 yaitu :

1. Instansi Pemerintah

Instansi pemerintah merupakan organisasi sektor publik yang berbentuk pemerintahan dalam suatu Negara terdiri dari : 
a. Pemerintah Pusat termasuk di dalamnya adalah kementerian, misalnya departemen tenaga kerja, departemen dalam negeri, departemen sosial, departemen keuangan dan lain - lain. Lembaga dan Badan Negara seperti KPU, KPK dan lain - lain.

b. Pemerintah Daerah, misalnya satuan kerja perangkat daerah seperti dinas perhubungan, dinas kesehatan, dan lain sebagainya.

2. Organisasi Nirlaba Milik Pemerintah, terdiri dari

a. Organisasi nirlaba milik pemerintah misalnya perguruan tinggi,rumah sakit negeri.

b. Yayasan - yayasan milik pemerintah misalnya Badan Layanan Umum (BLU) dan Badan Layanan Umum Daerah (BLUD)

3. Organisasi Nirlaba Milik Swasta

Jadi dapat di simpulkan organisasi sektor publik terdiri dari 3 organisasi, yang mempunyai tujuan masing - masing yaitu untuk tidak menghasilkan laba tetapi mempunyai tugas masing- masing yaitu untuk mempertanggung jawabkan laporan keuangan untuk setiap periode.

\subsection{Akuntansi Pemerintah Pusat}

Sistem Akuntansi Pemerintah Pusat (SAPP) adalah sistem terpadu yang menggabungkan prosedur manual dengan proses elektronis dalam pengambilan data, pembukuan dan pelaporan semua transaksi keuangan, asset, utang dan ekuitas seluruh entitas Pemerintah Pusat (Moh. Mahsun dkk 2012 : 173).

\subsubsection{Tujuan Sistem Akuntansi Pemerintah Pusat}

Dalam setiap organisasi maupun non organisasi mempunyai tujuan untuk mencapai segala apa yang di ingikan, begitu juga dalam pemerintahan, untuk mencapai hasil yang baik tentunya memilik tujuan awal seperti apa yang di kemukakan (Sujarweni 2015:145) dalam buku akuntansi sektor publik tujuannya yaitu :

1. Melindungi Kekayaan Pemerintah Pusat dan Instansi - instansinya dengan cara pencatatan, Pemprosesan dan pelaporan transaksi keuangan pemerintah yang konsisten sesuai dengan standar dan praktek akuntansi yang diterima secara umum.

2. Memberikan informasi yang akurat, tepat waktu, dan dapat dipercaya tentang keuangan pemerintah pusat, sebagai dasar penilaian kinerja, dan untuk menentukan ketaatan pada anggaran dan untuk tujuan akuntabilitas.

3. Memberikan informasi keuangan yang bermanfaat sebagai bahan perencanaan, pengelolaan dan pengendalian kegiatan dan keuangan pemerintah.

\subsubsection{Klasifikasi Sistem Akuntansi Pemerintah Pusat}

Akuntansi Pemerintah pusat dapat diklasifikasin beberapa bagian menurut pandangan (Suwarjeni 2015 : 146) dan (Moh. Mahsun dkk 2012 : 176), yaitu :

1. Sistem Akuntansi Pusat (SiAP)

Sistem akuntansi pusat (SiAP) dilaksanakan oleh direktorat Jenderal Perbendaharaan (Ditjen PBN) dan terdiri dari :

a. SAKUN (Sistem Akuntansi Kas Umum Negara ) yang menghasilkan laporan Arus Kas dan Neraca Kas Umum Negara (SAKUN)

b. SAU (Sistem Akuntansi Umum) yang menghasilkan laporan realisasi anggaran dan Neraca SAU. Pengolahan data dalam rangka penyusunan laporan keuangan SAU dan SAKUN, dilaksanakan oleh unit - unit Ditjen PBN yang terdiri dari :

Kantor Pelayanan Perbendaharaan Negara (KPPN)

Kantor Wilayah Ditjen Perbendaharaan (Kanwil Ditjen PBN)

Kantor pusat Ditjen Perbendaharaan.

2. Sistem Akuntansi Instansi (SAI) 
Sistem Akuntansi Instansi (SAI) digunakan untuk menghasilkan pelaporan posisi keuangan dan operasi keuangan pada Kementerian Negara/Lembaga. Setiap Kementerian Negara/ Lembaga wajib menyelenggarakan SAI untuk menghasilakan laporan keuangan.

Sistem Akuntansi Instansi (SAI) terdiri dari:

a. Sistem Akuntansi Keuangan (SAK)

Subsistem dari SAI yang terdiri serangkaian prosedur yang saling berhubungan untuk mengolah dokumen sumber dalam rangka menghasilkan informasi untuk penyusunan Laporan Keuangan berupa Laporan Realisasi Anggaran (LRA), Neraca dan Catatan atas Laporan Keuangan dari Satuan Kerja sesuai ketentuan yang berlaku. Sistem Akuntansi Keuangan terdiri dari :

Sistem Akuntansi tingkat Unit Akuntansi Kuasa Pengguna Anggaran (SAUAKPA)

Sistem Akuntansi tingkat Unit Akuntansi Pembantu Pengguna Anggaran Wilayah (SA-UAPPA-W)

Sistem Akuntansi Tingkat unit Akuntansi Pembantu Pengguna Anggaran Eselon I (SA-UAPPA-E), dan

Sistem Akuntansi tingkat unit Akuntansi Pengguna Anggaran (SA-UAPA)

b. Sistem Informasi Manajemen dan Akuntansi Barang Milik Negara (SIMAKBMN)

Subsistem dari SAI yang terdiri dari serangkaian prosedur yang saling berhubungan untuk mengolah dokumen sumber dalam rangka menghasilkan informasi untuk penyusunan neraca dan Laporan Barang Milik Negara (BMN) serta laporan manajerial lainnya sesuai ketentuan yang berlaku. BMN adalah semua barang yang dibeli atau diperoleh atas beban Anggaran Pendapatan dan Belanja Negara atau berasal dari perolehan lainnya yang sah. Sistem Informasi Manajemen dan Akuntansi (BMN) terdiri dari :

Sistem Akuntansi tingkat Unit Akuntansi Kuasa Pengguna Barang (SAUAKPB)

Sistem Akuntansi tingkat Unit Akuntansi Pembantu Pengguna barang Wilayah (SA-UAPPB-W)

Sistem Akuntansi tingkat Unit Akuntansi Pembantu Pengguna Barang Eselon I (SA-UAPPB-E1). Dan

Sistem Akuntansi tingkat Unit Akuntansi Pengguna Barang (SA-UAPB).

\subsection{Sistem Informasi Manajemen}

Menurut (Eti Rochaety dkk 2015 : 10 ) Sistem informasi manajemen merupakan perpaduan antara Sumber Daya Manusia dan aplikasi teknologi informasi untuk memilih, menyimpan, mengolah dan mengambil kembali data dalam rangka mendukung proses pengambilan keputusan sebuah perusahaan.

\subsubsection{Sistem Informasi Akuntansi}

Sistem Informasi akuntansi menurut (Krismiaji, 2014 : 4) adalah sebuah sistem yang memproses data dan transaksi guna menghasilkan informasi yang bermanfaat untuk merencanakan, mengendalikan dan mengoperasikan bisnis.

\subsection{Peraturan Perundang - undangan Sistem Informasi Manajemen dan Akuntansi Barang Milik Negara}

\subsubsection{Dasar Hukum}

Landasan Hukum Pengelolaan Barang Milik Negara :

1. Undang - undang Nomor 17 Tahun 2003 tentang keuangan Negara

2. Undang - undang Nomor 1 Tahun 2004 tentang Perbendaharaan Negara 
3. Peraturan Menteri Keuangan Nomor 24 Tahun 2005 tentang standar akuntansi pemerintah

4. Peraturan Pemerintah Nomor 6 Tahun 2006 tentang Pengelolaan Barang Milik Negara/Daerah

5. Peraturan Menteri Keuangan Nomor 96/PMK.06/2007 tentang tata cara Pelaksanaan pengunaan,pemanfaatan, penghapusan, dan Pemindahtanganan barang milik Negara

6. Peraturan Menteri Keuangan Nomor 120/PMK.06/2007 tentang Penatausahaan Barang Milik Negara.

\subsection{Sistem Informasi Manajemen dan Akuntansi Barang Milik Negara (SIMAK BMN)}

Lahirnya SIMAK BMN merupakan langkah mudah dalam mengelola asset/kekayaan Negara mulai dari manual ke elektronik/komputerisasi dan lebih mudah dipahamioleh para petugas pencatat dan penanggungjawab asset/kekayaan negara baik di tingkat satuan kerja (satker) sampai tingkat kementerian.

SIMAK BMN sebagai sistem akuntansi selayaknya diselenggarakan oleh unit organisasi akuntansi BMN dengan memegang prinsip-prinsip sebagai berikut :

1. Ketaatan : yaitu prinsip akuntansi barang milik Negara yang dilakukan harus sesuai dengan peraturan perundang- undangan dan prinsip akuntansi yang berlaku.

2. Konsistensi : pencatatan akuntansi barang milik Negara dilakukan secara berkesinambungan sesuai dengan peraturan yang berlaku.

3. Kemampubandingan : pencatatan akuntansi barang milik Negara menggunakan klasifikasi standar sehingga menghasilkan laporan yang dapat dibandingkan antar periode akuntansi.

4. Materialitas : pencatatan akuntansi barang milik negara dilaksanakan dengan tertib dan teratur sehingga seluruh informasi yang memengaruhi keputusan dapat diungkapkan.

5. Obyektif : pencatatan akuntansi barang milik Negara dilakukan sesuai dengan keadaan yang sebenarnya.

6. Kelengkapan : pencatatan akuntansi barang milik Negara harus mencakup seluruh transaksi yang terjadi.

\subsubsection{Jenis - Jenis Transaksi SIMAK BMN}

Untuk mengetahui jenis - jenis transaksi yang ada dalam akuntansi badan milik

Negara Rahardiyanti dkk (2012:4) menjelaskan secara detail yaitu :

1. Saldo Awal

Merupakan saldo BMN pada awal tahun anggaran berjalan atau awal tahun mulai diimplementasikannnya SIMAK-BMN yang merupakan akumulasi dari seluruh transaksi BMN tahun sebelumnya.

2. Perolehan BMN

Merupakan transaksi penambahan BMN yang tahun tanggal perolehannya sama dengan tahun anggaran berjalan. Transaksi perolehan BMN meliputi :

a. Pembelian, merupakan transaksi perolehan $\mathrm{BMN}$ dari hasil pembelian yang menggunakan dana APBN

b. Transfer Masuk, merupakan transaksi perolehan BMN hasil perpindahan BMN dari satu UAKPB kepada UAKPB lain dalam lingkup pemerintah pusat.

c. Hibah, Merupakan perolehan BMN hasil perpindahan BMN dari satu UAKPB kepada pihak ke 3 diluar lingkup pemerintah pusat.

d. Rampasan, merupakan Transaksi perolehan BMN hasil rampasan berdasarkan putusan pengadilan. 
e. Penyelesaian Pembangunan,merupakan transaksi perolehan BMN hasil penyelesaian pembangunan berupa bangunan/gedung dan BMN lainnya yang telah diserahterimakan dengan Berita Acara Serah Terima.

f. Pembatalan Penghapusan, merupakan pencatatan BMN hasil pembatalan penghapusan yang sebelumnya telah dihapuskan atau dikeluarkan dari pembukuan.

g. Reklasifikasi Masuk, merupakan transaksi BMN yang sebelumnya telah dicatat dengan klasifikasi BMN yang lain, transaksi yang berkaitan dengan transaksi keluar.

h. Pelaksanaan dari Perjanjian / Kontrak, merupakan pemanfaatan tanah milik pemerintah pusat oleh pihak lain dengan mendirikan bangunan dan/atau sarana, berikut fasilitasnya, kemudian didayagunakan oleh pihak lain tersebut dalam jangka waktu tertentu yang telah disepakati, untuk selanjutnya tanah beserta bangunan dan/atau sarana, berikut fasilitasnya, diserahkan kembali kepada Pengelola Barang setelah berakhirnya jangka waktu.

3. Perubahan BMN

Transaksi perubahan BMN meliputi :

a. Pengurangan Kuantitas/Nilai, merupakan transaksi pengurangan kuantitas BMN

b. Pengembangan, merupakan transaksi pengembangan BMN yang dikapitalisir yang mengakibatkan pemindahbukuan dari BI Ekstrakomptabel ke BI intrakomptabel atau perubahan satuan/nilai BMN dalam BI Intrakomptabel.

c. Perubahan Kondisi,merupakan pencatatan perubahan kondisi BMN

d. Koreksi Perubahan Nilai/Kuantitas, merupakan koreksi pencatatan atas nilai/ kuantitas BMN yang telah dicatat sebelumnya.

e. Perubahan/Pengembangan BMN dari penyerahan Aset Tetap Hasil Renovasi, merupakan pencatatan asset yang dinilai renovasinya sudah diserah terimakan dari

f. pihak lain.

g. Perubahan nilai koreksi tim penertiban Aset, merupakan dilakukan untuk melakukan perekam atas barang - barang BMN hasil koreksi dari Tim penertiban barang milik Negara (penilaian kembali).

4. Penghapusan BMN

Transaksi penghapusan BMN meliputi:

a. Penghapusan, merupakan transaksi untuk menghapus BMN dari pembukuan berdasarkan suatu surat keputusan penghapusan oleh instansi yang berwenang.

b. Transfer Keluar, merupakan transaksi penyerahan BMN dari satu UAKPB kepada UAKPB lain dalam lingkup pemerintahan.

c. Hibah, merupakan penyerahan BMN pada pihak ketiga

d. Reklasifikasi Keluar, merupakan transaksi BMN ke dalam klasifikasi BMN yang lain.

e. Koreksi Pencatatan, merupakan transaksi untuk mengubah catatan BMN yang telah dilaporkan sebelumnya. 


\section{PENELITIAN}

\subsection{Jenis Penelitian}

Jenis Penelitian ini menggunakan penelitian kualitatif. Menurut (Noor 2012:34) penelitian kualitatif sebagai suatu gambaran kompleks, meneliti kata - kata, laporan terinci dari pandangan responden dan melakukan studi pada situasi yang alami.

\subsection{Tempat dan Waktu Penelitian}

Tempat yang dipilih untuk melakukan penelitian adalah Kantor Imigrasi Kelas II Tahuna, JL Pelabuhan Tahuna. Waktu Penelitian mulai bulan Juni 2017 sampai dengan selesai.

\subsection{Metode Pengumpulan Data}

\section{Jenis Data}

Kuncoro (2013: 145) menyatakan jenis data terbagi 2 jenis yaitu:

1. Data kuantitatif adalah data yang diukur dalam suatu skala numerik (angka)

2. Data kualitatif adalah data yang tidak dapat diukur dalam skala numerik (artinya data yang disajikan dalam bentuk kata-kata)

Penelitian ini menggunakan jenis data yang bersifat kualitatif dimana data yang disajikan dalam bentuk kata-kata atau uraian kalimat.

\section{Sumber Data}

Sumber data terbagi menjadi dua bagian yaitu data primer dan data sekunder .

1. Data Primer

Menurut Ibrahim (2015 : 68 ) Data primer adalah segala informasi, fakta, dan realitas yang terkait atau relevan dengan penelitian, dimana kaitan atau relevansinya sangat jelas, bahkan secara langsung.

2. Data Sekunder

Data Sekunder adalah segala informasi, fakta dan realitas yang juga terkait atau relevan dengan penelitian, namun tidak secara langsung, atau tidak begitu jelas relevansinya.

Untuk mendapatkan data penelitian ini, data yang dikumpulkan berasal dari sumber data primer yaitu data yang diperoleh secara langsung melalui wawancara. Selain itu dari sumber data primer, data yang diperoleh penulis juga berasal dari data sekunder yaitu dengan cara melakukan pencarian data dengan membaca dan mempelajari bukubuku, catatan serta dokumen lainnya yang berhubungan dengan SIMAK BMN.

\section{Teknik Pengumpulan Data}

1. Wawancara

2. Dokumentasi

\subsection{Metode Analisis}

Metode yang digunakan untuk menganalisis data dalam pembahasan ini adalah metode deskriptif dengan pendekatan kualitatif. Pendekatan kualitatif adalah cara penelitian yang menekankan pada aspek pendalaman data demi mendapat kualitas dari hasil penelitian (Ibrahim, 2015 : 52). Metode analisis ini digunakan untuk mengetahui kinerja dari SIMAK BMN dilihat dari Kualitas, factor penghambat dan pendukung, Ketepatan Waktu dan kemudahaan penggunaan SIMAK BMN. Proses ini didahului dengan pengumpulan data serta informasi yang diperoleh dari pihak terkait yaitu kantor imigrasi kelas II Tahuna. Selanjutnya mengolah data serta informasi yang telah diperoleh kemudian dari hasil tersebut ditarik kesimpulan dan memberikan saran atau masukan. 


\section{HASIL ANALISIS DAN PEMBAHASAN}

\subsection{Hasil Penelitian}

Evaluasi Sistem Informasi Manajemen dan Akuntansi Barang Milik Negara di Kantor Imigrasi Kelas II Tahuna

Kantor Imigrasi Kelas II Tahuna mulai berlakukan aplikasi SIMAK BMN pada tahun 2015, dengan adanya SIMAK BMN sangat membantu proses penyusunan laporan Barang Milik Negara. Secara teknis, operasional dan ekonomis penggunaan SIMAK BMN di Kantor Imigrasi Kelas II Tahuna memberikan dampak yang cukup signifikan baik dari efektivitas dan efisien waktu dibandingkan menggunakan Microfost Exel. Sedangkan tujuan pengguna teknologi SIMAK BMN tidak hanya berfungsi sebagai saran pendukung atau pelengkap saja, akan tetapi merupakan sistem yang dapat mempermudah semua kegiatan inventarisasi dan pengambilan keputusan dalam rangka mencapai tujuan organisasi khususnya terkait pengelolaan Barang Milik Negara. Untuk itu SIMAK BMN sangat membantu bagi percepatan transparansi dan akuntabilitas laporan keuangan. Karena SIMAK BMN berbasis komputer sangatlah rentan terhadap virus yang bisa mengganggu kinerja operator, untuk itu pada aplikasi SIMAK BMN di khususkan menggunakan 1 (satu) komputer agar terhindar dari virus, selain itu komputer tersebut harus mempunyai anti virus yang up to date serta selalu memback up data pada media penyimpanan lain.

\section{Kualitas Informasi}

Untuk melihat kualitas dari aplikasi SIMAK BMN dapat dilihat dari 4 (empat) karakteristik yang merupakan prasyarat normativ yang diperlukan agar suatu laporan keuangan pemerintah dapat dikatakan memenuhi kualitas yang dikehendaki, yaitu :

1. Relevan

SIMAK BMN bisa dikatakan relevan, karna informasi yang termuat dalam neraca BMN dapat mempengaruhi keputusan dalam laporan keuangan, dengan hadirnya SIMAK BMN pada kantor Imigrasi sangat membantu mereka dalam pengambilan keputusan. Dan munculnya SIMAK BMN semua pekerjaan dapat diselesaikan dengan tepat waktu, bahkan informasi yang dihasilkan oleh SIMAK BMN dapat memprediksi hasil yang akan datang berdasarkan hasil di masalalu.

2. Andal

Informasi yang dihasilkan dari SIMAK BMN pada kantor imigrasi yaitu neraca BMN berdasarkan daftar Barang Milik Negara dan nilai - nilai dari tahun ke tahun, untuk itu penyajian menghasilkan informasi yang jujur serta dapat diverifikasi dan dapat diuji kembali.

3. Dapat dibandingkan

Perbandingnya dapat dilihat setelah menggunakan SIMAK BMN dan belum dapat dilihat melalui laporan keuangan dari tahun pertahun, karena SIMAK BMN diberlakukan di kantor Imigrasi mulai tahun 2015, untuk itu pada tahun sebelumnya kantor Imigrasi masih menggunakan secara manual untuk mengisi daftar BMN dan perhitungan nilai BMN dari tahun pertahun, akan tetapi sekarang lebih mudah karena sudah menggunakan aplikasi SIMAK BMN.

4. Dapat dipahami

Informasi yang disajikan dalam laporan $\mathrm{BMN}$ dapat dipahami oleh pengguna dan dapat disesuaikan dengan batasan pemahaman pengguna. Tetapi pada kantor Imigrasi untuk operator baru yang di tunjuk sebagai operator SIMAK BMN belum memiliki pengetahuan yang memadai mengenai SIMAK BMN, karena operator tersebut belum mengikuti pelatihan khusus untuk aplikasi SIMAK BMN maka dari itu para operator masih mempelajari informasi yang dimaksud. 


\section{Ketepatan Waktu}

SIMAK BMN sangat membantu proses pembuatan Neraca BMN, dengan adanya SIMAK BMN perkejaan yang dilakukan sangat membantu operator dalam pengisian daftar BMN, sebelum adanya SIMAK BMN kantor imigrasi melakukan laporan BMN secara manual yaitu menggunakan Microsoft exel dengan memakai rumus dan menulis kembali daftar barang milik Negara, untuk itu pada laporan semesteran membuat operator BMN sangat sulit untuk mengerjakan bahkan harus memiliki waktu yang banyak. Dengan diberlakukan aplikasi SIMAK BMN di kantor imigrasi perkejaan sangat mudah dikerjakan dan selalu tepat waktu setiap laporan semesteran yang di laporkan setiap 6 (enam ) bulan, dan tidak mempersulit operator SIMAK BMN.

\section{Kemudahan Penggunaan SIMAK BMN}

Dari informasi yang dihasilkan bahwa SIMAK BMN sangat mudah digunakan dalam penanganan Barang Milik Negara. Akan Tetapi pada Kantor Imigrasi Kelas II Tahuna operator SIMAK BMN kurang memahami secara detail mengenai SIMAK BMN. Sebelum digantikan dengan operator yang baru, operator SIMAK BMN dikantor imigrasi sangat memahami karena telah mengikuti pelatihan SIMAK BMN dan menerima bimbingan teknik pengeporasian SIMAK BMN.

\section{Faktor Pendukung Dan Penghambat dalam SIMAK BMN}

Setelah melewati berbagai proses wawancara yang dilakukan pada kantor Imigrasi Kelas II Tahuna dapat disimpulkan bahwa factor pendukung SIMAK BMN yaitu,

1. Adanya dukungan Pemerintah dalam rangka mewujudkan pengelolaan Barang Milik Negara yang akurat dan akuntabel.

2. Adanya dukungan kepala satuan kerja untuk operator SIMAK BMN agar Barang Milik Negara tidak terjadi salah pengimputan. Contohnya operator harus mengikuti pelatihan SIMAK BMN yang diadakan kantor yang berwenang.

Sedangkan factor penghambat BMN yaitu,

1. Terjadi kesalahan dalam pengimputan / error dalam SIMAK BMN

2. Sering terkena virus

3. Kurangnya dana dalam rangka peningkatan kualitas Sumber Daya Manusia (Operator SIMAK BMN)

\subsection{Pembahasan}

\section{Evaluasi Sistem Informasi Manajemen dan Akuntansi BMN}

Dalam Penerapan SIMAK BMN yang antara lain yaitu pencatatan dan pelaporan asset / kekayaan Negara tersebut tertuang dalam PP Nomor 6 Tahun 2006 tentang Pengelolaan Barang Milik Negara / Daerah pasal 71 ayat 1 dan 2 yaitu : Kuasa Pengguna Barang harus menyusun laporan barang kuasa pengguna semesteran (LBKPS) dan Laporan Barang Kuasa pengguna Tahunan (LBKPT) untuk disampaikan kepada pengguna barang (satuan Kerja). Untuk kantor Imigrasi setiap laporan Barang Milik Negara selalu dilaporkan kepada KPNL selambat - lambatnya 10 (sepuluh) hari setelah berakhir satu semester, begitu pula untuk laporan tahunan selambat - lambatnya 15 (lima belas) hari sebelum berakhir anggaran. Kemudian dari semua satuan kerja harus mengarsip laporan Barang Milik Negara secara tertib dan menyimpannya dengan baik. Untuk itu pada kantor imigrasi sudah mengikuti aturan yang sudah di tetapkan oleh pemerintah pusat, akan tetapi masih banyak kendala yang dihadapi entah melalui aplikasi SIMAK BMN atau dari operator SIMAK BMN yang kurang memahami aplikasi SIMAK BMN dan belum mengikuti pelatihan khusus SIMAK BMN. Dan juga untuk penatausahaan asset yang berupa Tanah, masih terdapat sedikit masalah yaitu sertifikat tanah yang belum lengkap. Hasil penelitian ini juga didukung (Novia, 2014) bahwa untuk melihat penerapan suatu sistem dalam satuan kerja dibutuhkan pedoman agar penerapan tersebut dapat diterapkan dengan baik tanpa adanya penyelewengan dan kesalahan. 
Laporan Keuangan yang dihasilkan merupakan tanggung jawaban pelaksanaan anggaran oleh unit - unit akuntansi, baik entitas akuntansi maupun entitas laporan. Laporan keuangan kementerian / lembaga yang dihasilkan unit akuntansi instansi tersebut terdiri dari Laporan Realiasasi Anggaran, Neraca, dan Catatan Atas Laporan Keuangan. Sementara di kantor Imigrasi kelas II Tahuna telah melaksanakan semua laporan yang dimaksud, salah satunya yaitu Neraca, karena didalam neraca terdapat sebagian Laporan Barang Milik Negara.

Tabel 4.1

Perbandingan posisi Aset Tetap pada tahun anggaran 2016 s.d 2017.

\begin{tabular}{|l|l|l|l|l|}
\hline No. & \multicolumn{1}{|c|}{ Nama Perkiraan } & \multicolumn{1}{|c|}{ Tahun 2016 } & \multicolumn{1}{c|}{ Tahun 2017} & \multicolumn{1}{c|}{$\begin{array}{c}\text { Naik/Turun } \\
\text { Nan }\end{array}$} \\
\hline 1 & Tanah & 394.905 .250 & 129.405 .250 & $-67 \%$ \\
\hline 3 & Peralatan dan Mesin & 1.742 .254 .500 & 3.176 .562 .119 & $82,32 \%$ \\
\hline 4 & Gedung dan Bangunan & 2.545 .595 .552 & 2.605 .975 .050 & $2,37 \%$ \\
\hline 5 & Jalan dan Jembatan & 60.379 .498 & 0 & $0,00 \%$ \\
\hline & Aset Tetap Lainnya & 20.000 .000 & 20.000 .000 & $0,00 \%$ \\
\hline
\end{tabular}

Sumber : Kantor Imigrasi Kelas II Tahuna

Catatan : Untuk tahun 2017 hanya sampai pada bulan juni ( Laporan Semseter 1)

Dari tabel diatas dapat dijelaskan bahwa pada tahun 2016 ke tahun 2017 terjadi perubahan yaitu :

1. Pada akun tanah pada tahun 2016 tercatat sebesar Rp. 394.905.250,- sedangkan akun tanah pada tahun 2017 sebesar Rp. 129.405.250,- terjadi pengurangan asset tanah sebesar Rp. 265.500.000,-

2. Pada akun Peralatan dan Mesin pada tahun 2016 tercatat sebesar Rp. 1.742.254.500,sedangkan nilai peralatan dan mesin pada tahun 2017 adalah sebesar Rp. 3.176.562.119,-- terjadi kenaikan sebesar Rp. 630.966.647,-

3. Pada akun Gedung dan Bangunan pada tahun 2016 tercatat sebesar Rp. 2.545.595.552,- sedangkan nilai gedung dan bangunan pada tahun 2017 yaitu sebesar Rp. 2.605.975.050,- terjadi kenaikan sebesar Rp.60.015.498,--

4. Pada akun Jalan dan Jembatan, tidak terjadi perubahan asset yaitu tahun $2016 \mathrm{Rp}$. 60.379.498,-

5. Pada akun Asset Tetap lainnya tidak terjadi perubahan asset bila dibandingkan dengan tahun anggaran 2016, yaitu Rp.20.000.000,-

\section{Proses Pelaporan Barang Milik Negara di Kantor Imigrasi Kelas II Tahuna}

1. Proses Bulanan / Semesteran

a. Menunjuk dan menetapkan petugas akuntansi BMN

b. Menyiapkan rencana pelaksanaan sistem akuntansi BMN

c. Mengevaluasi hasil kerja operator

d. Menelaah buku invetaris, buku barang bersejarah, dan buku persediaan serta mendatangani laporan kondisi barang (LKB), kartu inventaris barang (KIB), daftar inventaris ruangan (DIR), daftar inventaris lainnya (DIL) dan laporan BMN.

e. Membuat laporan BMN pada akhir semester

f. Meminta pengesahan selaku penanggung jawab UAKPB atas laporan BMN

g. Menyampaikan laporan BMN dan berita acara rekonsiliasi dan UAKPB ke kantor pelayanan kekayaan Negara dan lelang selambat - lambatnya 10 (sepuluh) hari setelah berakhir suatu semester.

h. Mengarsip Laporan BMN secara tertib

2. Proses Akhir Periode Akuntansi 

a. Melakukan pengecekan ulang kondisi BMN yang berada diruangan masing - masing
b. Mencatat perubahan kondisi BMN yang telah disahkan oleh penanggung jawab ruangan ke dalam aplikasi
c. Membuat laporan kondisi barang (LKB)
d. Membuat laporan BMN tahunan berdasarkan saldo yang ada
e. Menyampaikan laporan BMN tahunan dan LKB ke KPKNL selambat - lambatnya 15 hari setelah berakhir tahun anggaran
f. Mengarsip semua laporan BMN secara tertib
g. Melakukan proses back up data dan tutup tahun
Keluaran / Laporan yang dihasilkan dari Sistem Informasi Manajemen dan Akuntansi
1. Daftar Barang Milik Negara
2. Kartu Inventaris Barang (KIB)
3. Daftar Inventaris Ruangan (DIR)
4. Laporan Posisi BMN di Neraca Barang Milik Negara :

\section{KESIMPULAN DAN SARAN}

5.1 Kesimpulan

1. Pengawasan yang dilakukan dalam mengevaluasi SIMAK BMN tidak hanya berasal

2. dari pihak Kantor Imigrasi melainkan juga dari KPKNL. Hanya saja terdapat kendala dari yaitu dari pihak operator SIMAK BMN yang belum memahami dengan baik mengenai aplikasi SIMAK BMN.

3. Hasil kerja yang dihasilkan oleh SIMAK BMN dapat dilihat dari segi kualitas, Kemudahan penggunaan SIMAK BMN, Ketepatan waktu, dan factor pendukung dan penghambat.

4. Proses pelaporan sudah mengikuti peraturan yang berlaku yaitu Laporan Barang kuasa pengguna semesteran dan Laporan Barang kuasa pengguna Tahunan yang telah mengikuti peraturan Pemerintah Nomor 06 tahun 2006 mengenai pengelolaan barang milik Negara/ daerah.

\subsection{Saran}

Berdasarkan hasil penelitian maka dapat diberikan saran sebagai berikut :

1. Sebagai operator Sistem Informasi Manajemen dan Akuntansi Barang Milik Negara (SIMAK BMN) harus mengikuti pelatihan khusus yang diadakan oleh lembaga yang berwenang, agar operator tersebut bisa menguasai setiap akun dan pengisian daftar Barang Milik Negara kedalam aplikasi SIMAK BMN.

2. Berhubung perkembangan teknologi informasi yang terus berkembang, maka dari pihak kantor Imigrasi kelas II Tahuna harus menyediakan sarana computer yang lebih agar dalam pengerjaan aplikasi dan pengisian BMN dapat berjalan dengan baik tanpa hambatan oleh virus dan kerusakan yang lain. Dan jaringan internet yang memadai dalam menerima informasi.

\section{DAFTAR PUSTAKA}

Anggita Kiki Rahardiyanti. 2012. Evaluasi efektivitas SIMAK BMN di Departemen Kebudayaan dan Pariwisata republic Indonesia. Journal of applied finance and accounting. Vol 5, No 12012

Azhar Susanto.2016.Sistem Informasi Akuntansi. Bandung ; Lingga jaya 
Aprilia Rizki Savitri,2012. Persepsi kualitas Sistem Informasi Manajemen dan Akuntansi Barang Milik Negara terhadap kinerja karyawan (studi kasus pada 26 skpd di wilayah jember). Universtia jember

Christabella Pingkan A Patitingan. 2016. Pengaruh pelatihan online Support dan Peer adviceties terhadap kepuasan Sistem Informasi Manajemen Barang Milik Negara.

Dwijanatri Prakasita N,2015. Perancangan Sistem Informasi Akuntansi penjualan dan persediaan dicentral steak and coffe boyolali. Universitas Negeri Yogyakarta. Yogyakarta

Efendi,Rizal.2013. Accounting Principle: Prinsip - Prinsip Akuntansi berbasis SAK ETAP. Jakarta. PT Raja Grafindo Persada.

Ety Rochaety, Faizal Ridwan, dan Tupi setyowati, 2012. Sistem Informasi Manajemen. Edisi 2. Penerbit mitra wacana media, 2013. Jakarta

Febriana F Albugis.2016. Penerapan Sistem Akuntansi Keuangan Daerah dalam mewujudkan transparansi dan akuntabilitas keuangan pemerintah daerah Provinsi Sulawesi Utara. Jurnal EMBA. Vol.4. No.3. Hal. 078-089

Ferawati,2012. Analisis Penatausahaan asset tetap dan penerapannya melalui Sistem Informasi Manajemen dan Akuntansi (studi kasus pada satuan kerja PPPTMGB "lemigas") Universitas Indonesia

Hasrudin,2014. Efektivitas Sistem Informasi Manajemen dan Akuntansi Barang Milik Negara difakultas pertanian universitas sebelah maret Surakarta.

Irwin Nugroho,2012. Sistem Informasi Penerimaan siswa baru berbasis web dengan PHP dan SQL. Universitas Negeri Yogyakarta.

Juwita R.2013. Pengaruh Implementasi Standar Akuntansi Pemerintah dan Sistem Informasi Akuntansi terhadap kualitas laporan keuangan. Jurnal Trikonomika. Vol.12 No.2 Hal.20-214

Kuncoro. 2013. Metode Penelitian Kualitatif. Jakarta

Krismiaji, 2012. Sistem Informasi Akuntansi. Yogyakarta. Akademi Manajemen perusahaan YKPN.

Mahayuddin, Jeanny M Fatimah 2016, Evaluasi Sistem Informasi Manajemen (SIMDA BMD) dalam mendukung inventarisasi asset daerah dikabupaten Majene. Jurnal Komunikasi Kareba. Vol. 5 No 1 Januari 2016

MA, Ibrahim, Dr.2015. Metodologi penelitian kualitatif. Bandung;Alfabeta

Mahsun, Mohammad, Firma, dan Purwanugra, Andre, Heribertus , 2012. Akuntansi sector public. Cetakan kelima. Edisi ketiga. Penerbit BPF E-Yogyakarta. Yogyakarta

Mubarak N, 2015. Analisis Penerapan Sistem Informasi Manajemen (SIMDA Keuangan) Dalam mendukung kecepatan Laporan Dan Pengawasan keuangan oleh Badan Pengelolaan Keuangan Daerah Kabupaten Wajo (Tesis). Makassar, Universitas Hasanudin.

Nitiya Widyatasari, 2012. Analisis efektivitas Sistem Informasi Akuntansi penggajian karyawan pada RSUD kota Semarang. Universitas Diponegoro semarang. Semarang

Nuraini Rahayu, 2014. Penerapan Sistem Informasi Akuntansi Barang Milik Negara Pengadilan Tinggi Manado.

Noor, Juliansyah, Dr.2012. Metodologi penelitian ; Skripsi,Tesis, disertasi, dan karya ilmiah. Cetakan pertama.Jakarta ; Prenadamedia

Novia Rahmawati,2014. Penerapan Sistem Informasi Manajemen dan Akuntansi Barang Milik Negara di kantor pusat humaniora, kebijakan kesehatan dan pemberdayaan masyarakat Surabaya.

Puryanta, 2014. Evaluasi empiris kinerja atas aplikasi Sistem Informasi Manajemen dan Akuntansi Barang Milik Negara. Unniversitas Maria Kudus 
Ratmono, Dwi, Dr dan Mahfud Sholihin.2015. Akuntansi Keuangan Daerah berbasis Akrual. Cetakan pertama. Penerbit UPP STIM YKPN. Semarang

Riyanto, Puji agus, 2015. Akuntansi Pemerintah Daerah berbasil Acrual. Cetakan 1. Penerbit Pustaka Pelajar. Bandung

Roby Firmansyah/2014. Pengaruh Kefektifan Sistem Informasi Manajemen dan Akuntansi Barang Milik Negara terhadap Manajemen Aset Barang Milik Negara (studi pada Kantor Pelayanan kekayaan dan Lelang Kota Malang).

Suhardi,Zulfa Fitri/2016. Evaluasi Kapabilitas Sistem Informasi Manajemen dan Akuntansi Barang Milik Negara di Satuan Kerja TNI Angkatan Laut. Unniversitas Mercu Buana Jakarta

Sunyoto D, 2014. Metode penelitian kuantitatif kualitatif dan R\&D. Bandung, Alfabeta.

Suwardjomo.2013. Akuntansi Pengantar. Edisi ketiga, cetakan keenam. BPFE,Yogyakarta

Sujarweni, Wiratna, V.2015. Akuntansi sector publik. Penerbit pustaka baru press. Yogyakarta

\section{Sumber Undang : Undang :}

Undang - undang Nomor 17 Tahun 2003 tentang keuangan Negara

Undang - undang Nomor 1 Tahun 2004 tentang Perbendaharaan Negara

Peraturan Menteri Keuangan Nomor 24 Tahun 2005 tentang standar akuntansi pemerintah

Peraturan Pemerintah Nomor 6 Tahun 2006 tentang Pengelolaan Barang Milik Negara/Daerah 